\title{
A ARTE HOLANDESA
}

\author{
Dr. Mansueto Kohnen, O. F. M. \\ Prof. de História das Artes - Rio
}

Os Países Baixos mandaram suas obras magistrais e seus mestres para a Espanha, Itália, França e Germânia. Tiveram excepcional cotação, em determinados períodos, mòrmente na Espanha. Os mestres neerlandeses deixaram seus vestígios, por exemplo no Prado de Madrid, nos "Uffizii" em Florença, principalmente no assim chamado Portinari-altar, da autoria de van der Goes. E Rembrandt assemelha-se, em muitas fases de sua vida artística, aos germânicos.

A arte neerlandesa, como a germânica, vive da existência camponesa e burguesa, enquanto a romana e italiana, se baseiam na vida da cidade, respectivamente citadino-aristocrática. Sua essência camponesa reflete-se na pintura, enquanto a vida burguesa se espelha, de preferência, na escultura e arquitetura. Um dos maiores pintores holandeses é denominado "Bauernbrueghel", quer dizer Brueghel, o pintor (como tantos outros) da vida dos campos, dos sítios, dos jogos aldeães, das brigas, dos banquetes e das quermesses. Tudo é descrito com grande exatidão e carinho. Os paisagistas - pela origem são citadinos - vêm a natureza com olhar claro, sóbrio e quase calculador, nada de fantasismo, nada de monumentalidade, como Giotto o fêz. A maneira neerlandesa de representação do camponês e da natureza bucólica é única em tôda a Europa, superando neste particular a germânica.

No gênero burguês existe maior afinidade entre a Germâninia e os Países Baixos, se bem que êstes o cultivam com maior exclusividade, criando uma poderosa burguesia em sua pintura de grupos, de guildes, de lares e outras associações ou em sua arquitetura de municipalidades, lojas para venda de panos e moradias. 
Porém, nem o camponês nem o burguês formam, no fundo, - elemento decisivo da arte holandesa. Seu herói verdadeiro é a natureza: a terra do campo, as dunas e os diques, o pôrto, o céu e o mar (Cfr. Paul Claudel: Vom Wesen der hollaendischen Malerei. Wien, 1937). Não há nenhuma arte européia em que os elementos cósmicos dominem tão poderosamente como na neerlandesa. Poucos são seus artistas (por exemplo Bosch, Rembrandt e Hals) que possuem enorme fôrça fisiognômica e sentido metafísico. Mas tôdas as fases produtivas da pintura neerlandesa sentiram-se apaixonadamente ligadas à natureza. Surgem, na fase de transição entre gótica e renascença, tôrres altas com carrilhões, como por exemplo em Bruegge e Mecheln, para que estas vozes melodiosas recordem ao viajante o céu nublado ou claro-azul.

Os irmãos van Eyck amalgamam, no século $X V$, de maneira corajosa e inovadora, a descrição de temas religiosos com a paisagem livre. Da "Adoração do Cordeiro" no altar de Gent emergem no horizonte, atrás de prados e florestas, a cidade Gent, rica em tôrres, e a catedral de Utrecht. Sim, nos séculos XVI e $X V I I$, a pintura de paisagens dos neerlandeses conquista a hegemonia absoluta na Europa: representa magistralmente prados pacatos e campos férteis, cidades envoltas em neblina perto do mar, partidas de portos cheias de sedução e perigos, partidas de canoa em fantásticas noites de luar, nuvens densas que parecem casar o horizonte com a terra, patinação em lagos limpos e campos infindos de neve - e a gente ganha a convicção firme e acalentadora dos artistas: esta é a terra, pela qual somos e vivemos, ela nos dá suprema alegria para coração e sentidos!

De fato, o neerlandês procura captar sua natureza através da pintura e êle é dono de um extraordinário talento de pintura. E a pintura é a rainha de tôdas as artes em terras holandesas. A Germânia é-lhes superior em realizações esculturais e arquitetônicas, jamais em colorido original. Coisa semelhante se dá na arte gráfica: apesar das obras de Lukas van Leyden (1494-1533), Hercules Seghers (1589 - ca. 1640) e Rembrandt, os Países Baixos quase nunca tiveram artistas como a Germânia no gênero gráfi- 
co, enquanto os neerlandeses são os grandes criadores da côr. Se a arte gráfica visa mais o sôbre-sensivel e o a-sensivel, a pintura (neerlandesa) é movimentada por grande sensibilidade e sensualidade.

\section{Os principais mestres:}

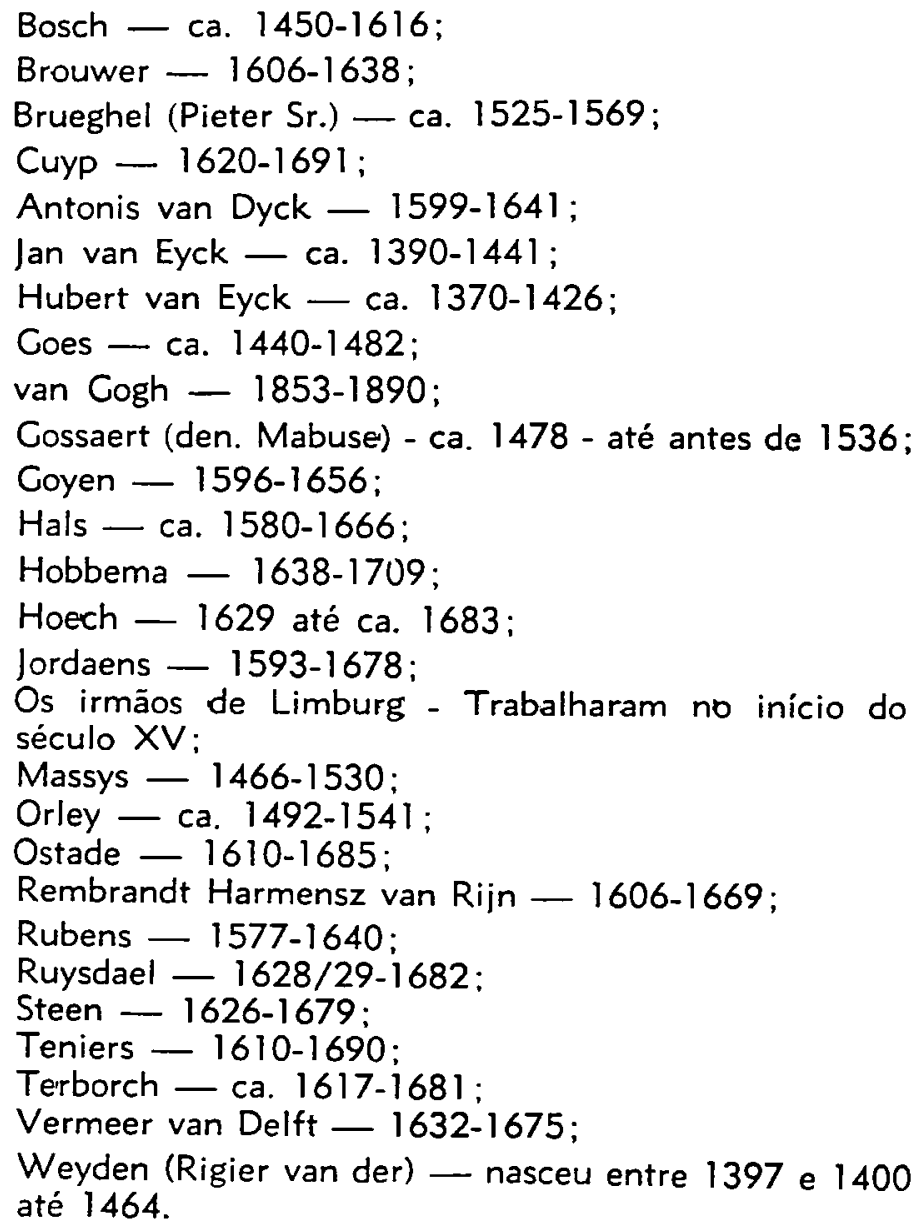

Conhecemos dois grandes auges da pintura neerlandesa:

a) Século XV: os irmãos de Limburg na obra do "Livro de Horas" para o duque von Berry (1410-1416) e os irmãos Hubert e Jan van Eyck na altar de Gent. Se os primeiros foram os inovadores, os outros sintetizaram as fôrças do passado, dominando 
todo o século mencionado. Desenvolvem fecundamente êste estilo: Weyden e Goes.

b) Após um rápido intermezzo de influência italiana (Massys, Mabuse e Orley), inicia-se o segundo florescimento. O genial Brueghel está na fase de transição: ainda medieval em suas interpretações filosófico-alegóricas, indica o futuro em seus grandes panoramas de paisagens, verdadeiros poemas heróicos das estações do ano.

Vem a Pseudo-Reforma e cria nova polaridade interior. Dois mestres refletem a cisão:

$\left.1 .{ }^{\circ}\right)$ RUBENS corporifica o sul com uma arte alegre, sensual, festiva e barroca.

$\left.2 .^{\circ}\right)$ REMBRANDT caracteriza as províncias do Norte com sua cultura mais simples e calma, às vêzes também mais robusta e burguesa.

$\mathrm{Na}$ obra de Rubens ainda estáo unidos o elemento aristocrático e camponês. Seus sucessores cultivam cada um determinada facêta: Van Dyck é o pintor elegante da aristocracia de Gênova e Londres, enquanto Jordaens representa incansàvelmente os deleites camponeses.

Ao lado de outros paisagistas importantes, dos pintores originais da vida camponesa (Brouwer) e dos entusiastas da vida do lar holandês (Hoech) observa-se, não raras vêzes, nas obras de muitos artistas, um traço nítido de abastada vida burguesa; uma espécie de auto-satisfação e insipidez.

VAN GOCH é o grande representante da pintura moderna neerlandesa. Também êle vai ao encontro da natureza e da paisagem (no sul da França). A natureza é-lhe símbolo das fôrças criativas, que dormitam na terra. Ele ainda confirma uma vez: por tôda a evolução da pintura neerlandesa passa o signo do amor pela natureza maternal, que abrange tudo.

Que é o essencial das duas grandes épocas da pintura neerlandesa? Os primeircs neerlandeses se distinguem pelo máximo de realização: os objetos ficam metàlicamente duros ante o nosso olhar, pois, existe uma observação por nada turvada e uma pura reprodução da verdadeira natureza, como observa Christoffel. E, em comparação com a germânica, mais pobre em visões, porém, mais rica em gravação firme e clara. No altar de Gent, 
de van Eyck, os sêres celestiais até existem! Este é o típico nesta arte: tudo "existe" simplesmente com enorme intensidade. Ademais, a arte neerlandesa é geralmente uma arte de alto controle espiritual: expressões apaixonadas de dor (auges da arte italiana e espanhola) são quase desconhecidas. Sofrimento e alegria são contidos, severa e calmamente. Porém esta reserva não exclui fôrça sensual. Isto provam justamente os primeiros neerlandeses. Sua sensualidade é forte e clara, comparável ao sol matutino.

Esta arte tenta, ao mesmo tempo, ser lógica e construtiva, até certo ponto, espacial. Desconhece, como a germânica, irrupções do homem interior, porque é por demais sóbria e sabedora; não enigmática. Esta arte é, até na pintura, plástica.

Estas afirmações são sublinhadas pela côr. Vejamos o altar de Portinari em Florença, obra principal de Hugo van der Goes: as côres frias reluzem festivamente - a vestimenta azul da Madona, o branco azulado da capa esquerda, o purpúreo e verde da capa direita dos anjos, no fundo os prados verdes e o céu azul. $O$ artista pinta carinhosamente as flôres na frente de modo exátíssimo: uma obra-prima de micro-arte na totalidade do quadro. No espaço arquitetônicamente delimitado desdobra-se uma sossegada e rica vida da alma. Absorta, a Madona olha a criancinha, quase que perdida no chão duro, de tão pequena, e que, todavia, forma o âmago de tudo, atraindo os olhares de todos. Os pastôres que adoram, manifestam três atitudes: piedosa e súbita curiosidade, admiração carinhosa e adoração muda. Pastôres, pais $e$ anjos formam, porém, personagens isoladas, em contraste com a arte italiana, que conhece em tudo a concatenação espontânea e social. É uma obra que, ainda neste conjunto piedoso, deixa adivinhar uma longitude isoladora, que experimenta a alta beleza das coisas e dos sêres de estranha solidão e silêncio.

$O$ segundo florescimento (séculos $X V I$ e XVII) desconhece êstes traços. Vive em tudo a vida burguesa. $E$, todavia, ela permanece algo fria, pouco acessivel, dura e quebradiça, algo impedida e não libertada até nas festas camponesas de Brueghel e nos retratos de grupos. Novamente refulge, como na primeira fase, o colorido singular nesta segunda fase. 
Além dêstes aspectos técnicos, o segundo florescimento se vê colocado ante novas tarefas: êle experimenta a mais rica discussão na pintura com o problema do INFINITO! Rubens cria, acima de tudo, a infinita plenitude de vida. Se êle pinta mulheres nuas ou grupos de bacantes, se representa caçadas de leões ou batalhas, se descreve a queda dos anjos ou a subida dos bem-aventurados, sempre empresta, em corpos poderosamente movimentados, colorido e expressão especiais ao turbilhão da vida. Vermellha é sua côr preferida; côr do sangue e do fogo e da refulgente fôrça do corpo - e ao lado do vermelho coloca o louro dos cabelos e da carne macia e exuberante, sublinhando tudo com a magia excepcional de pincel admirável. Vive nêle desmedidamente a sadia vitalidade não gasta dos nórdicos. Rubens é uma fôrça elementar.

$A$ arte do século $X V I I$ conhece ainda outro motivo novo: - do espaço ilimitado. Rubens o colocou numa verdadeira festa de sua terra natal em suas paisagens. Esta variedade do motivo do infinito perpassa, rica e maduramente, tôda a fase em questão. Em tudo - num pedacinho de terra, num banco de areia, numa muralha ensolarada, no colorido variegado e finíssimo das nuvens $e^{\prime}$ do mar, nas velas dos navios ou nas neblinas outonais - em tudo vive, graças ao emprêgo magistral da côr, o segrêdo vivo da paisagem.

Mas não só a natureza ampla, também a casa estreitamente delimitada transforma-se em símbolo do infinito. Há um quarto que dá passagem a outro quarto e êste conduz à rua. Os vidros deixam passar uma luz amável e em contornos indistintos balanceiam longínquas copas de árvores. Quadros de paisagens com o céu alto penduram nas paredes, reassumindo em outra modalidade o tema do infinito. Um espelho capta às vêzes a visão do lado contrário do quarto: livre de tôda estreiteza aparece nos limites de um quarto um mundo pequeno, sossegado e rico, realmente um mundo.

Rembrandt (1606-1669), ao pintar um espaço interior, o dissolve numa penumbra suspensa, que devora os contornos: não existe parede firme. Tudo é sonho e mistério. Um ondular enigmático no qual, de vez em quando, refulgem côres como 
jóias. O velho Rembrandt ainda acentua mais êstes aspectos: transmite quietude e paz a homens inquietos e irrequietos.

Quietude e paz respiram as obras dêste grande mestre, mormente seu auto-retrato, pintado por volta de 1663 e conservado no Iveagh-Museu, em Londres. Este, no entanto, parece recordar as palavras goetheanas: "Alles Vergaengliche ist nur ein Gleichnis" - Tôdas as coisas passageiras são apenas uma comparação...

Rembrandt, o Velho, no auto-retrato acima mencionado, é ainda um simbolo da arte e situação neerlandesas através dos tempos: da pobreza e solidão dos derradeiros anos de vida galgou os degraus de uma suprema grandeza real. Reproduz, sem encobrir nada, seu semblante saturado de sofrimentos. Sem desviar-se do próprio espelho, grava os muitos pensamentos nas rugas da fronte carregada de problemas. Porém, no fundo, já ficou tudo resolvido, pois a posição do representado, as formas e as côres o anunciam e o enunciam.

O auto-retrato irradia quietude. Não há nêle linha sùbitamente interrompida ou tensa. Não há gesto brusco para dilacerar a unidade e harmonia. Rembrandt, calmo e grande, segura quase como seu cetro! - o pincel, sua varinha mágica, que manda sôbre as idéias e as domina. Misteriosamente abarca o círculo - êste símbolo preferido do infinito - a totalidade velada do ser. Côres lendárias e preciosas emergem e refulgem do fundo escuro. Tudo se une e se casa mansamente num amálgama macio e, no fim, tudo é um emanar de côres quentes por entre as quais parecem anunciar-se, de vez em quando, o longínquo fulgor $e$ brilho de glória vindoura. O Rembrandt idoso passa, em seus derradeiros auto-retratos, além das fronteiras do puramente humano e apodera-se de seu Eu transcendental.

A arte holandesa presenteia-nos com um tríplice encontro com o infinito: na atualização da plenitude de vida flutuante, na descoberta de um espaço infinito e na ampliação de um quarto ou de um auto-retrato rembrandtiano - estas são as realiza- 
ções imperecíveis e benfazejas da pintura neerlandesa do século XVII.

Os mestres neerlandeses, embora diferentes em forma, fundo e personalidade, estão arraigadosi numa burguesia livre e assegurada. A natureza constitui, para êles, na plenitude de sua existência, uma fôrça feiticeira e encantadora. Esta arte mostra, sob - aspecto formal, uma técnica admirável e grande clareza na estruturação, unindo a tudo isto a máxima sensibilidade pelos deleites sensuais da côr e do colorido. 